\title{
SUSTAINABLE URBAN PLANNING AND RISK ASSESSMENT OF EARTHQUAKE HAZARDS IN TURKEY
}

\author{
C. Tarhan ${ }^{\mathrm{a},}$ D. Deniz ${ }^{\mathrm{b}}$ * \\ ${ }^{a}$ Dokuz Eylul University, Dept. of Management Information System, 35160 Izmir, Turkey - cigdem.tarhan@deu.edu.tr \\ b Izmir University of Economics, Dept. of Industrial Design, 35330, Izmir, Turkey - deniz.deniz@ieu.edu.tr
}

Commission VI, WG VI/4

KEY WORDS: Sustainable, Urban, Design, Development, City

\begin{abstract}
:
Cities in the developing world are facing increased risk of disasters and the potential of economic and human losses from natural hazards is being exacerbated by the rate of unplanned urban expansion and influenced by the quality of urban management. Risk assessment has come to be regarded by many analysts as a critical part of the development of sustainable communities. The risk assessment function has been linked to issues such as environmental stewardship and community planning. The crucial point is the linkage between hazard mitigation efforts and urban planning in the context of building sustainable communities. But this conceptual linkage has been difficult to implement in practice. The resolution of this difficulty and a clarification of the essential linkage of hazard mitigation to urban planning will require a broader definition and a reformulation of the risk assessment function. Turkey is one of the countries that support the international sustainability. However, it is hardly related urban planning with sustainability in Turkey. At this point, this paper aims to introduce the integration of sustainability and risk assessment in Turkey. The components of the sustainable communities have been discussed and earthquake risk in Turkey has been explained with the recent past examples. At the end of the study, the relationship between risk assessment and the sustainable urban planning in Turkey has been examined in terms of Turkish urban planning system.
\end{abstract}

\section{INTRODUCTION}

Cities are facing an identity problem in the $21^{\text {st }}$ century. Cities became metropolis in the past; but, they are turning into megapolis nowadays. During this transformation period, the urbanization concept is inescapable and irreversible. At this urbanization process, cities in the developing world are exposed to increased risk of disasters and the potential of economic and human losses from natural hazards is being exacerbated by the rate of unplanned urban expansion and influenced by the quality of urban management. As a critical part of the development of the sustainable communities analysts have pointed out the importance of risk assessment (Valiela et al., 2000; Goldschalk, 2003; Pearce, 2003). This function should be linked to issues such as environmental management and community planning, additionally, the linkage between hazard mitigation efforts and urban planning in the context of building sustainable communities (Tobin, 1999). However, this conceptual linkage has been difficult to implement in practice (Mileti and Gailus, 2005). The resolution of this difficulty and a clarification of the essential linkage of risk assessment to urban planning will require a broader definition and a reformulation of the risk assessment function.

Sustainability is the existence of harmony for built and nonbuilt environment into perpetuity. It is a continuous period, a non-stop effort for the achievement of environmental, socioeconomic, and cultural goals. In the $21^{\text {st }}$ century, many projects and research studies include indicators in order to measure urban sustainability (While et al., 2004; Munda, 2006; Barredo and Demicheli, 2003). These indicators are used in different scales and shapes in different countries. Turkey is one of the countries that support the international sustainability. However, it is hardly related urban planning with sustainability in Turkey. At this point, this paper aims to introduce the integration of sustainability and risk assessment in Turkey.

\section{THE COMPONENTS OF THE SUSTAINABLE COMMUNITIES}

Sustainable communities are communities, which respect the needs of future economically, socially and environmentally. Sustainable communities improve people's quality of life by providing safe and healthy environment to live and work in. These communities also encourage 'Life Quality' with welldesigned and well-managed public spaces and other facilities. Sustainable communities include the principles of sustainable development. These principles mainly are meeting the needs of existing and future generations; integrating the social, economic and environmental components of the community as well as respecting the needs of other communities (Zelinka and Dean, 2001).

Sustainable communities also need to initiate long-term strategic plans for reducing the negative impacts of natural disasters, which include working with the collaboration including the citizens, non-governmental organizations, security forces, academicians, etc. These kinds of collaborations and long-term national programmes also help communities to use their sources in a more sustainable way and therefore; it is crucial in order to create sustainable and liveable communities (Deniz, 2008).

\footnotetext{
* Corresponding author.
} 
"Sustainable communities are places where people want to live and work, now and in the future. They meet the diverse needs of existing and future residents, are sensitive to their environment, and contribute to a high quality of life. They are safe and well planned communities that offer equality of opportunity and good services for all” (ODPM 2005).

There are some points that are essential for creating successful sustainable communities and cities. However, it is crucial to understand the relationship between these components and the built environment for creating sustainable and safer communities. To do that, at first step, the components of the sustainable communities need to be considered carefully.

Sustainable communities should be active and safe. In that case, sustainable communities should offer a sense of community identity and belonging; opportunities for varied activities, low levels of crime and effective and environmentally friendly policing etc. (Wekerle \& Whitzman 1995). Besides, sustainable communities should offer visionary leadership and enable active and effective participation by individuals and organisations. One of the crucial points that the sustainable communities should provide places for people to live that is environmentally sensitive in every aspect. In other words, sustainable communities seek to minimise the effects of climate change and natural hazards such as earthquakes, etc. They also should protect the environment, minimise waste and make efficient use of natural resources, encouraging a lifestyle that minimises negative environmental impacts and thus create cleaner, safer and greener neighbourhoods, etc. (see in Figure 1)

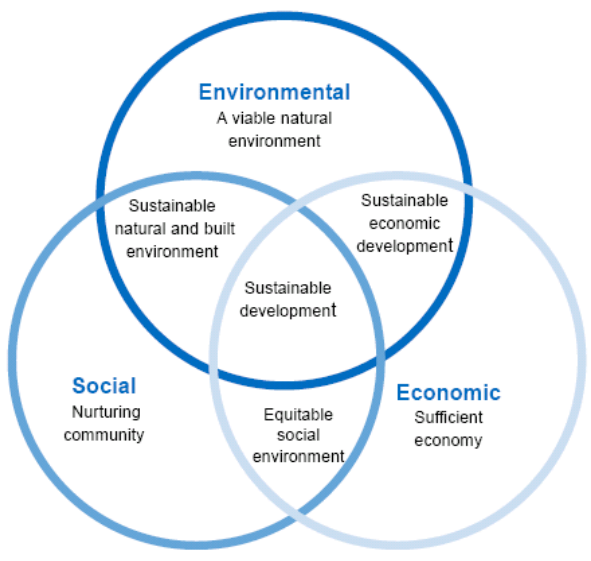

Figure 1. The main components of sustainable communities Source: URL1

Sustainable communities are user-friendly public spaces in terms of scale, density, design and layout, etc. These communities also include mixed-use development and public spaces that promote health. Sustainable communities should also offer public transport facilities and good access to regional, national and international communications networks, even in the time periods of struggling with natural disasters, such as earthquakes, floods, etc. Sustainable communities should serve public, private, community and voluntary services that are appropriate to people's needs and accessible to all at all times. They also should have well-performing institutions; high quality local health care and social services, integrated where possible with other services. In addition to that, it is important to have these opportunities for everyone now and in the future. Finally, sustainable communities should carefully recognise and respect the rights of individuals and aspirations of others also to be sustainable; regarding the needs of future generations in current decisions and actions (ODPM 2005).

Considering these features, it is possible to say that creating safer and liveable public spaces is crucial in order to create sustainable communities. In that case, another crucial point is that, these issues should be considered carefully from the planning to the design and management stage in order to have a great achievement.

\section{EARTHQUAKE RISK IN TURKEY}

Turkish earthquake zones map, shown in Figure 2, prepared by the Ministry of Public Works and Settlement and approved by the Government of Turkey and published in 1996. The earthquake zones, determined by using the acceleration contour map, have calculated with the probabilistic method. It assumes that a normal construction, which has 50 years of economical life, may not be exposed larger than these expected maximum acceleration values with $90 \%$ probability. For the important constructions or buildings that have longer economical life, maximum acceleration values should be calculated (URL1, 2013). In Table 1, the earthquake history, caused fatalities, injuries and building damages, is summarized from 1990 to 2013. Figure 3 presents the post-earthquake situation in Golcuk.

Turkish cities have a potential of an intensive growth and construction phase because of in-migration linked to employment or education. These potentials have not been built to contemporary building standards; therefore, rapid construction has a negative effect on the environmental quality of the cities. This is the result of the unplanned and unregulated building process in Turkey, despite the fact that this is a country that has frequent natural disasters including floods, landslides and earthquakes (Akinci, 2004).

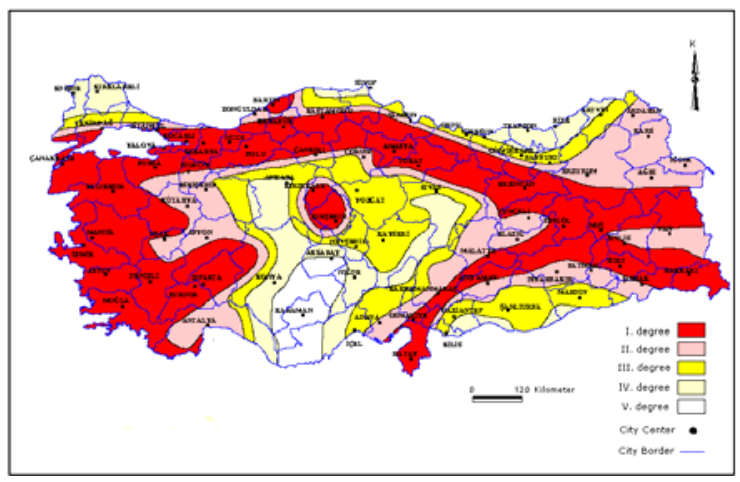

Figure 2. Earthquake Zones of Turkey Source: URL2, 2013

1st degree earthquake zone : more than $0.4 \mathrm{~g}$ 2nd degree earthquake zone : between $0.3-0.4 \mathrm{~g}$ 3rd degree earthquake zone : between $0.2-0.3 \mathrm{~g}$ 4th degree earthquake zone : between $0.1-0.2 \mathrm{~g}$ 5th degree earthquake zone : less than $0.1 \mathrm{~g}$ g: gravity $\left(981 \mathrm{~cm} / \mathrm{s}^{*} \mathrm{~s}\right)$ 
International Archives of the Photogrammetry, Remote Sensing and Spatial Information Sciences,

Volume XL-4/W1, 29th Urban Data Management Symposium, 29 - 31 May, 2013, London, United Kingdom

\begin{tabular}{|l|c|r|r|r|r|r|}
\hline Earthquake & Date & \multicolumn{1}{l|}{ Mg. } & Population of cities & Fatalities & \multicolumn{1}{c|}{ Injured } & Building Damage \\
\hline Erzincan & 1992 & 6.8 & 90.000 & 653 & 3850 & 4000 \\
\hline Dinar & 1995 & 6.0 & 35.000 & 96 & 240 & 4500 \\
\hline Adana & 1998 & 6.3 & 100.000 & 145 & 1041 & 400 \\
\hline Golcuk & 1999 & 7.4 & 2.500 .000 & 17.127 & 43.953 & \multirow{2}{*}{100.000} \\
\hline Duzce & 1999 & 7.2 & 65.000 & 845 & 4948 & \\
\hline Bingol & 2003 & 6.4 & 68.000 & 176 & 520 & 2260 \\
\hline Van & 2011 & 7.2 & 1.000 .000 & 600 & 4100 & \\
\hline
\end{tabular}

Table 1. Earthquakes in Turkey since 1990 Source: URL3, 2013

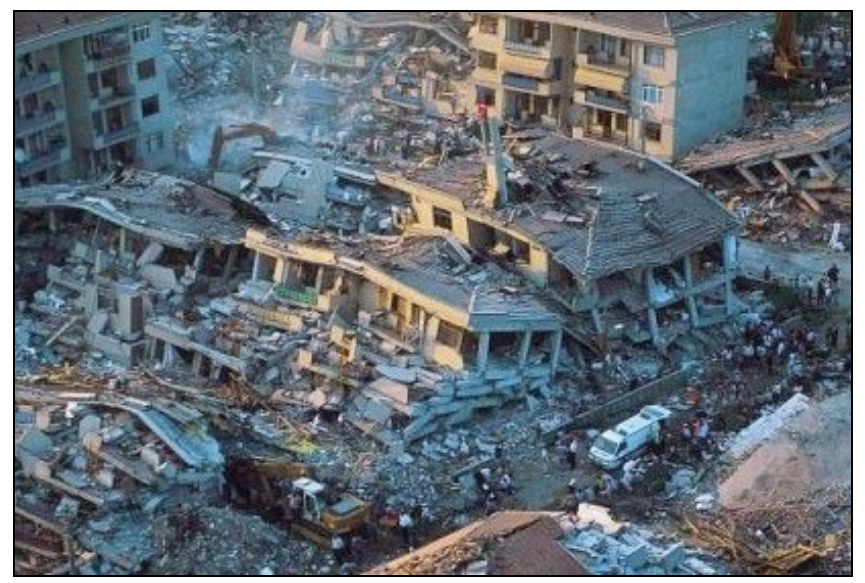

Figure 3. The post-earthquake (Golcuk) Source: URL4, 2013

\section{RISK ASSESSMENT AND SUSTAINABLE URBAN PLANNING IN TURKEY}

Researchers generally agree that land use planning is an important tool for reducing losses in natural disasters (Oprivovic and Tzeng, 2003; Olshansky, 2001). The linkage of sustainable urban development (land use planning) and risk assessment, like its linkage to environmental sustainability, is both logical and inherent. Sustainable urban development includes the development of disaster resilient communities. The concept of risk assessment begins with the realization that most disasters are not unexpected. These two concepts are connected to decisions that humanity makes about development and they relate to economic development and the built environment (Sengezer and Koc, 2005).

Turkish urban planning system could be classified as:

a. National Strategies and Development Plans (over $1 / 100.000)$

b. Regional Plans $(1 / 100.000)$

c. Environmental Order Plans (1/50.000 - 1/100.000)

d. Construction and Development Plans (1/25.000 $1 / 5.000$ and $1 / 100.000$ )

Although there are several scale plans for planning studies, there are some structural and organizational problems about the planning system in Turkey (Oner and Saritas, 2005; Ercet, 2012; Kuruoglu and Ergen 2000). The problems are listed as:

- lack of spatial planning system integrated with national development planning,

- lack of coordination between institutions,
- partial implementations in planning and authorization conflict,

- $\quad$ numerous authorities for the same spatial scale.

Whether sustainable or not, development has a spatial reference, since all developments are taking place at certain places on Earth, which can be represented by Cartesian coordinates $(\mathrm{x}, \mathrm{y}, \mathrm{z})$. Thus, for a region, whether a municipality, district, periphery, or country, there can be important spatial heterogeneity or dissimilarities, which in many cases ought to have particular consideration. However, the spatial dimension has often been ignored or been given low priority by groups planning environmental or sustainability indicators. Nowadays, with the expansion of Geographical Information System (GIS) and spatial databases, nobody denies the necessity of using these technologies in describing, analyzing, and understanding spatial phenomena.

The sustainability of a neighbourhood, region, or country is based on the governmental or local authorities and the civil society. In urban planning and broader in spatial development, these information technology tools are quite effective. But, what necessary, in any case, are data collection strategies as well as concepts for compiling, transforming, and interpreting existing data. The governmental departments, agencies, bodies, and services as well as the local authorities are a powerful lever for the development of such a system of urban sustainability indicators. This is because they have the strong mechanism of the state, which has a wealth of data that often remains untapped. 
In terms of civil society, the potential role of GIS is either a democratizing force or a disenfranchising force is a growing topic of conversation within the GIS community. When planning on the urban environment: what to adjust, what to organize, what to change, and what to leave as is important for planners and decision makers. The transformation of activities required by sustainable development put forward potentials for realizing better standards for quality of life. A key issue in this process is the urban sustainability indicators. By analyzing these indicators under their spatial reference, planners and decision makers are encoding numbers, percentages, etc. into digital representations which in turn help to further analyze and finally shape the proposals and recommendations.

GIS cannot be considered as the solution to spatial (sustainable) planning but a powerful tool facilitating the decision-making process. GIS technology in the appropriate hands can be a vehicle for different application scenarios: indicatively in effective and sustainable environmental management in tourism planning, urban transport ecological footprint analysis etc.

\section{CONCLUSION}

Sustainability is an important concept for cities, because urban population is continuously increasing. Cities are becoming the main areas of the sustainable development and this concept is transformed into sustainable urban development. It is a new and comprehensive approach toward viewing natural hazards and their impacts. People and societies must accept responsibility for hazards and disasters and they must take long-term precautions for dealing with their negative impacts on communities. It is crucial that, disasters and their negative effects are more likely to occur in unsustainable communities. With this in mind, all sustainable activities should identify the community's social, economic, and environmental aspects.

In the context of risk assessment, in order to achieve sustainable urban development, communities must become more active in determining where and how development proceeds. Local and central governments should evaluate their environmental resources and hazards. Additionally, they should also evaluate the extent of possible future losses. Consequently, long-term and comprehensive plans should be developed and applied for encouraging sustainability and creating sustainable communities.

\section{REFERENCES}

Akinci, F., 2004. The aftermath of disaster in urban areas: An evaluation of the 1999 earthquake in Turkey. Cities, 21(6), pp.527-536.

Barredo, J.I. and Demicheli, L., 2003. Urban sustainability in developing countries' megacities: modelling and predicting future urban growth in Lagos. Cities, 20(5), pp.297-310.

Deniz, D., 2008. Creating Safer and Sustainable Public Spaces by Using the Principles of Crime Prevention through Environmental Design, The Scientific and Technological Research Council of Turkey Awarded Scientific Research Report, London, UK.

Ercet, C., 2012. 'Strategic Plan’ and ‘Environment Plan’ (Cevre Duzeni Plani) in Turkey in the Context of a Question: "Can 'Environment Plan' be combined to 'Strategic Plan' in terms of
Preparation and Practice to Get a New Planning Type that is 'Strategic Spatial Planning, AESOP Conference 2012.

Godschalk, D., 2003. Urban Hazard Mitigation: Creating Resilient Cities. Natural Hazards, 4(3), pp.136-143.

Kuruoglu, M. and Ergen, E., 2000. The effects of economic development on project management in developing countries. Challenges Facing The Construction Industry in Developing Countries, Netherlands.

Mileti, D.S. and Gailus, J.L., 2005. Sustainable development and hazards mitigation in the United States: disasters by design revisited. Mitigation and Adaptation Strategies for Global Change, 10, pp.491-504

Munda, G., 2006. Social multi-criteria evaluation for urban sustainability policies. Land Use Policy, 23(1), pp.86-94.

ODPM, 2005. Sustainable Communities: People, Places and Prosperity. (A Five Year Plan from the Office of the Deputy Prime Minister).

Olshansky, R.B., 2001. Land use planning for seismic safety: Los Angeles county experience, 1971-1994. Journal of the American Planning Association, 67(2), pp. 173-184.

Oner, M.A. and Saritas, O., 2005. A systems approach to policy analysis and development planning: construction sector in the Turkish 5-year development plans. Technological Forecasting and Social Change, 72, pp. 886-911.

Opricovic, S. and Tzeng, G.H., 2003. Fuzzy multicriteria model for postearthquake land-use planning. Natural Hazards Review, 4(2), pp. 59-64.

Pearce, L., 2003. Disaster management and community planning, and public participation: how to achieve sustainable hazard mitigation. Natural Hazards, 28, pp.221-228.

Sengezer, B. And Koc, E., 2005. A critical analysis of earthquakes and urban planning in Turkey. Disasters, 29(2), pp. 171-194.

Tobin, G.A., 1999. Sustainability and community resilience: the holy grail of hazards planning?. Global Environmental Change Part B: Environmental Hazards, 1(1), pp. 13-25.

URL1: Pittsburg State University website, What is sustainability? http://www.pittstate.edu/office/president/ initiatives/sustainability/what-is-sustainability.dot

URL2: Republic of Turkey Prime Ministry, Disaster and Emergency Management Presidency, www.deprem.gov.tr, March 2013.

URL3: Turkish Statistical Institute, www.tuik.gov.tr, March 2013.

URL4: Erdal Sahan web site, www.erdalsahan.com, March 2013.

Valiela, I., Tomasky, G., Hauxwell, J., Cole, M.L., Cebrián, J. and Kroeger., K.D., 2000. Operationalizing sustainability: management and risk assessment of land-derived nitrogen loads to estuaries. Ecological Applications, 10, pp.1006-1023. 
International Archives of the Photogrammetry, Remote Sensing and Spatial Information Sciences, Volume XL-4/W1, 29th Urban Data Management Symposium, 29 - 31 May, 2013, London, United Kingdom

Wekerle, G.R. and Whitzman, C., 1995. Safe Cities- Guidelines for Planning, Design and Management. Van Nostrand Reinhold.

While, A., Jonas, A.E.G. and Gibbs, D., 2004. The environment and the entrepreneurial city: searching for the urban 'sustainability; fix' in Manchester and Leeds. International Journal of Urban and Regional Research, 28(3), pp.549-569.

Zelinka, A. and Dean, B., 2001. SafeScape: Creating Safer, More Livable Communities through Planning and Design. Planners Press, Chicago. 